\title{
A PRE-INDO-EUROPEAN PLACE-NAME: DALMATIA
}

Two years ago I ventured to suggest another etymon of the place name (hereafter PN) Ardeal, the Romanian form for Transylvania and, connected to this, I also explained the PN Dalmatia (Paliga 1986). I shall not rediscuss the whole topic, yet it is useful to briefly point the essentials of my hypothesis for a larger discussion. I started from the observation that the largely accepted hypothesis which sees Rom. PN Ardeal as a reflection of Hung. Erdély is not at all feasible, mainly from reasons of phonetic evolution, as long as the expected form should have been ${ }^{*} E r d e i$ or *Ardei. We can better understand the situation of this PN if placing it in a reasonable linguistic-comparative context. As a matter of fact the situation is simple enough: Ardeal is a compound of the type Ar-deal, ar- (a particle lost in vocabulary, probably akin to $a$ arunca, $a$ aruca "to cast away, throw") with the reconstructable meaning "over, far away", and deal "hill", also "forest", very frequent in Romanian place-names. The fact that $A r$-deal is a compound is also supported by obviously similar forms like Subdeal (also spelled Sub Deal) "at the foothill", Pe deal "on the hill", La deal "uphill". All these forms are frequent in the so-called minor toponomy as well as in vocabulary. Reverting to $A r$-deal, it should be also observed that the Medieval Latin form Trans-silvania and German Überwald (now replaced by Siebenbürgen) are loan-translations (calques) after Ar-deal . Hung. Erdély is also a calque but following the rules of derivation in Hungarian: noun + particle, i.e. Erdö-"forest" and -elu/-elv> -ely (cf. elöre "straightforward", elött "in front of"), as shown and accepted by all Hungarian linguists (cf. Kiss 1980 with further references). What is particularly interesting in this case is that the calque was doubled by a fortuitous similarity between Ar-deal and Erdély, which created a confusion of etymological analysis.

Another important point I tried to solve was to observe that what the linguistic investigation had to clarify was the situation of Rom. deal "hill", also "forest" as compared to the rare Slavic form dèlढ "hill". My hypothesis, proved by other parallels (see Table 1 below) is that this Slavic form has nothing to do with other two homophone roots: dël- "to make, create" (dëlo "work", artifact", etc.) and dël- "to divide, to part" (dëliti, etc.). Thus dell-" "hill" is, unlike the other two roots, nonSlavic, probably borrowed from the Balcanic substratum 1 . In this case, we must identify, obviously enough, a pre-INDO-EUROPEAN root ${ }^{*} D-L /{ }^{*} T-L-\left({ }^{*} D a L\right.$,

1 There can be little doubt now that Old Serbian délø "hill" and Bieloruss. dit "id.", already analyzed a century ago (Miklosich 1886: 45) do not reflect a proto-Slavic form but are borrowings. It is of course regrettable that e.g. in Šmilauer 1970: 54 the meanings "part" and "hill" of dèlढ̆ are grouped together, as long as they are different words with different etyma. 
${ }^{*} D e L-,{ }^{*} T a L-,{ }^{*} T e L-$, etc.) $)^{2}$ well analyzed by various linguists (e.g. Trombetti 1925 , Rostaing 1950, Faure 1977, Paliga n.d.). PN Dalmatia is also analyzable from this perspective ${ }^{3}$, being a compound of the type ${ }^{*} D a L-M a T-i a$. The second part of the PN is also of pre-IE origin, namely the root ${ }^{*} M a T(T)$ - "confused, labyrinthine", from which several meanings are derived, in this case the most probable being "bush, tree, forest" (see a detailed analysis of this root in Paliga 1989, in preparation). The general meaning of the compound Dal-mat-ia is therefore "forested highland". The spread of the pre-IE root ${ }^{*} D a L-/{ }^{*} D e L$ - is briefly sketched in Table 1 . The pre-IE origin of the PN Dalmatia is in full agreement with archaeological finds a very early Neolithic civilization being well documented along the Adriatic. The PN should be considered pre-Illyrian.

\section{REFERENCES}

Dečev, D., 1957. Die thrakischen Sprachreste. Wien: R. M. Rohrer.

Faure, P., 1977. Viata de fiecare zi în Creta lui Minos. Bucureşti: Eminescu (French original: La vie quotidienne en Crète au temps de Minos. Paris: Librairie Hachette 1973).

Kiss, L., 1980. Földrajzi nevek etimológiai szótára (an etymological dictionary of place-names). Budapest: Akadémiai kiadó.

Miklosich, F., 1886. Etymologisches Wörterbuch der slavischen Sprachen. Wien: Wilhelm Braumüller.

Paliga, S., 1986. Ardeal, Transilvania. "Tribuna" (Cluj), no. 8, 20 feb., pp. 1 and 6. 1989. Types of mazes. "Linguistica" 29 (forthcoming).

n.d. Byzantion. Indo-european şi pre-indo-european in relicte de limbă. Manuscript.

Rostaing, Ch., 1950. Essai sur la toponymie de la Provence. Paris: éd. d'Artrey.

Russu, I. I., 1969. Illirii. Bucureşti: Ed. Academiei.

Smilauer, Vl., 1970. Handbuch der slawischen Toponomastik. Praha: Academia. Trombetti, A., 1925. Saggio di antica onomastica mediterranea. "Arhiv za arbanasku starinu, jezik i etnologiju“ 3: 1-116, (reprinted in Studi Etruschi 13/1939: 263-310).

2 The paralellel variant ${ }^{*} D-R-{ }^{*} T-R-\left({ }^{*} D a R-,{ }^{*} D e R-,{ }^{*} T a R\right.$-, etc.) is also well documented (further examples in Paliga n.d.).

3 To my knowledge the accepted explanations for Dalmatia are three: (1) the first part of the PN would be connected to Alb. dele, delme "sheep" (Kiss 1980: 172), or (2) to IE *dhel-/*dhol- "vault, cavity" (Eng. dale), or (3) *dhel- "to shine" (Russu 1969: 191). The second part of the compound is unexplained. The purpose of this paper is to correct these inconsistent hypotheses. 
Table 1

Survey of the forms derived from the pre-IE root *D-L/*T-L- "prominence, hill, mountain"

\begin{tabular}{|c|c|c|c|c|c|c|c|}
\hline \multicolumn{2}{|c|}{ Illyrian } & \multirow{2}{*}{$\begin{array}{l}\text { Thracian } \\
\text { NL Dalátarba }\end{array}$} & \multirow{2}{*}{$\begin{array}{l}\begin{array}{l}\text { Romanian } \\
\text { (via Thracian) }\end{array} \\
\text { deal "hill, forest": }\end{array}$} & Greek & \multirow{2}{*}{$\begin{array}{l}\text { Etrusco- } \\
\text { Latin } \\
\text { Etr.tel }\end{array}$} & \multirow{2}{*}{$\begin{array}{l}\text { Provence } \\
\text { NL Tallard }\end{array}$} & \multirow{2}{*}{$\begin{array}{l}\text { Georgian } \\
\text { talaki }\end{array}$} \\
\hline $\mathrm{NPp}$ & Dalmatae, & & & $\begin{array}{l}\text { NI Delos } \\
\text { (Cyclades) }\end{array}$ & & & \\
\hline & Delmatae, & NSt Delkos & NR $A r$-deal & $\begin{array}{c}N M \operatorname{Delos}(1) \\
\text { (Boeotia) }\end{array}$ & "hill" & (*Tal-arn-u-) & "fertile" \\
\hline & Delmateis & & NL Subdeal, La deal, & NL Delphoi(2) & (? tular & NL Toulon & soil“ \\
\hline NR & Dalmatia & & $\begin{array}{l}\text { Peste deal, etc. } \\
\text { NL Delea }\end{array}$ & NL Tylissos & "boundary" & & \\
\hline NL & Dalmatas & & NL Talma & $\begin{array}{c}\quad \text { (Crete) } \\
\text { NM Talarus } \\
\text { NL Lepa-talea } \\
\quad \text { (Caria) }\end{array}$ & $\begin{array}{l}\text { Lat. tellus } \\
\text { "earth"(3) }\end{array}$ & & \\
\hline
\end{tabular}

Abbreviations: $\mathrm{NI}=$ nomen insulae, $\mathrm{NL}=\mathrm{n}$. loci, $\mathrm{NM}=\mathrm{n}$. montis, $\mathrm{NPp}=\mathrm{n}$. pupuli (ethnonym), NR $=\mathrm{n}$. regionis, $\mathrm{NSt}=\mathrm{n}$. stabuli Notes to Table 1

1 No connection with $\delta \tilde{y} \lambda_{0}\left(\delta \varepsilon \dot{\varepsilon} \lambda_{-}\right)$) "evident", which reflects IE "*dei-/*deiw- "to shine".

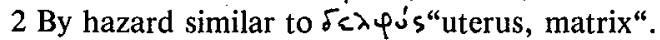

3 Lat. terra is derived from the parallel pre-IE root ${ }^{*} T-R-/^{*} D-R$ - not analyzed here. 
Povzetek

DALMATIA: PREDINDOEVROPSKI TOPONIM

Avtor se naslanja na novejše raziskave predindoevropskega jezikovnega fonda in je mnenja, da je toponim Dalmatia zloženka tipa $D A L-M A T$-ia, pri čemer sta prvi dve prvini predindoevropski, skupni pomen pa "gozdnata gorska dežela“. Toponim šteje za predilirski. 